\title{
ORIGINAL ARTICLE Perturbations in the apoptotic pathway and mitochondrial network dynamics in peripheral blood mononuclear cells from bipolar disorder patients
}

\author{
G Scaini ${ }^{1}$, GR Fries ${ }^{1}$, SS Valvassori ${ }^{2}$, CP Zeni ${ }^{3}$, G Zunta-Soares ${ }^{3}$, M Berk ${ }^{4,5,6,7}$, JC Soares ${ }^{3}$ and J Quevedo ${ }^{1,2,3,8}$
}

Bipolar disorder (BD) is a severe psychiatric disorder characterized by phasic changes of mood and can be associated with progressive structural brain change and cognitive decline. The numbers and sizes of glia and neurons are reduced in several brain areas, suggesting the involvement of apoptosis in the pathophysiology of BD. Because the changes in mitochondrial dynamics are closely related with the early process of apoptosis and the specific processes of apoptosis and mitochondrial dynamics in BD have not been fully elucidated, we measured the apoptotic pathway and the expression of mitochondrial fission/fusion proteins from BD patients and healthy controls. We recruited 16 patients with BD type I and sixteen well-matched healthy controls and investigated protein levels of several pro-apoptotic and anti-apoptotic factors, as well as the expression of mitochondrial fission/fusion proteins in peripheral blood mononuclear cells (PBMCs). Our results showed that the levels of the anti-apoptotic proteins Bcl-xL, survivin and $\mathrm{BCl}-\mathrm{xL} / \mathrm{Bak}$ dimer were significantly decreased, while active caspase-3 protein levels were significantly increased in PBMCs from BD patients. Moreover, we observed the downregulation of the mitochondrial fusion-related proteins Mfn2 and Opa1 and the upregulation of the fission protein Fis1 in PBMCs from BD patients, both in terms of gene expression and protein levels. We also showed a significantly decrease in the citrate synthase activity. Finally, we found a positive correlation between Mfn2 and Opa1 with mitochondrial content markers, as well as a negative correlation between mitochondrial fission/fusion proteins and apoptotic markers. Overall, data reported here are consistent with the working hypothesis that apoptosis may contribute to cellular dysfunction, brain volume loss and progressive cognitive in BD. Moreover, we show an important relationship between mitochondrial dynamics and the cell death pathway activation in BD patients, supporting the link between mitochondrial dysfunction and the pathophysiology of BD.

Translational Psychiatry (2017) 7, e1111; doi:10.1038/tp.2017.83; published online 2 May 2017

\section{INTRODUCTION}

Bipolar disorder (BD) is a chronic, debilitating illness with a global prevalence of up to $4.8 \%$, which is associated with medical and psychiatric comorbidity and increased standardized mortality ratios. ${ }^{1,2}$ Acute episodes are associated with cognitive and functional impairments, ${ }^{3}$ which tend to worsen with the progression of the illness. ${ }^{4-7}$ Despite superior cognitive capacity often present in at risk-individuals, ${ }^{8}$ individuals with a long-term course of illness present significant impairment in neuropsychological performance when compared to early-stage patients and controls. ${ }^{4,9}$

Although several different mechanisms have been proposed for the pathogenesis of $\mathrm{BD}$, its pathophysiology remains unknown. ${ }^{10}$ Numerous hypotheses have been postulated to underpin the neurobiology of $\mathrm{BD}$, including the interaction of molecular, cellular and behavioral mechanisms with susceptibility genes, environmental stressors and biochemical mechanisms. ${ }^{4}$ Regional reductions in central nervous system volume, which are likely due to the atrophy and loss of neurons and glial cells, may be linked to an increase or imbalance in apoptosis, ${ }^{11-13}$ and it is known that mitochondria play a critical role in the regulation of apoptosis. ${ }^{14} \mathrm{Kim}$ et al. $^{12}$ reported a significant decrease in the levels of Bcl-2 and brain-derived neurotrophic factor, whereas Bax, Bad and caspase-9/-3 levels were significantly increased, both in terms of protein and mRNA levels in postmortem brains of BD patients. A recent clinical study also showed an increase in the $\mathrm{Bax} / \mathrm{Bcl}-2$ ratio and increased cytochrome $c$ release and caspase- 3 activity in manic and depressed patients compared to healthy subjects. ${ }^{15}$ Similarly, lymphocytes from patients with BD present decreased expression of the HSP70, an anti-apoptotic factor, as well as a decrease in Bax levels in the cytosolic fraction, suggesting Bax activation and translocation to the mitochondria to induce apoptosis. ${ }^{16}$ Moreover, a study published by Fries et al. ${ }^{17}$ showed an increased percentage of early apoptotic cells in euthymic

\footnotetext{
${ }^{1}$ Translational Psychiatry Program, Department of Psychiatry and Behavioral Sciences, McGovern Medical School, The University of Texas Health Science Center at Houston, Houston, TX, USA; ${ }^{2}$ Laboratory of Neurosciences, Graduate Program in Health Sciences, Health Sciences Unit, University of Southern Santa Catarina, Criciúma, Brazil; ${ }^{3}$ Center of Excellence on Mood Disorders, Department of Psychiatry and Behavioral Sciences, McGovern Medical School, The University of Texas Health Science Center at Houston, Houston, TX, USA; ${ }^{4}$ Deakin University, IMPACT Strategic Research Centre, School of Medicine, Faculty of Health, Geelong, VIC, Australia; ${ }^{5}$ Orygen, The National Centre of Excellence in Youth Mental Health, Parkville, VIC, Australia; ${ }^{6}$ The Centre for Youth Mental Health, Department of Psychiatry, Parkville, VIC, Australia; ${ }^{7}$ Florey Institute for Neuroscience and Mental Health, the University of Melbourne, Parkville, VIC, Australia and ${ }^{8}$ Neuroscience Graduate Program, The University of Texas Graduate School of Biomedical Sciences at Houston, Houston, TX, USA. Correspondence: Professor JL de Quevedo, The University of Texas Medical School at Houston, Department of Psychiatry and Behavioral Sciences, 1941 East Road, Ste. 3140, Houston, TX 77054, USA.
}

E-mail: Joao.L.DeQuevedo@uth.tmc.edu

Received 6 March 2017; accepted 8 March 2017 
patients with $\mathrm{BD}$ when compared to controls, but no differences in overall cell viability, necrosis or late apoptosis, suggesting potential plasticity and an intervention opportunity.

Mitochondria are organelles responsible for multiple cellular functions, including ATP production, metabolism of reactive oxygen species and calcium homeostasis. ${ }^{18,19}$ Moreover, they represent a convergence point for death signals activated by both intracellular and extracellular stimuli, leading to the release of apoptogenic factors, such as cytochrome c, apoptosis-inducing factor, and SMAC/Diablo. ${ }^{20}$ In addition, recent studies indicate that mitochondrial fission/fusion machinery actively participates in the process of apoptosis, since dysregulation of mitochondrial dynamics leads to mitochondrial fragmentation. ${ }^{21,22}$ However, the specific processes of apoptosis and mitochondrial dynamics in $\mathrm{BD}$ have not been fully elucidated. To test the above hypothesis, we measured the protein levels of several pro- (Bax, Bad, Bak, Smac and active caspase-3) and anti-apoptotic factors ( $\mathrm{Bcl}-\mathrm{xL}$, $\mathrm{Bcl}-\mathrm{xL} / \mathrm{Bak}$ dimer, survivin and $\mathrm{Mcl}-1)$, the mRNA and protein expression levels of mitochondrial fission/fusion proteins (Mfn2, Opa1 and Fis1), and the mitochondrial content in peripheral blood mononuclear cells (PBMCs) from BD patients and healthy controls.

\section{MATERIALS AND METHODS}

\section{Subjects}

This study was carried out in accordance with the principles of the Declaration of Helsinki with approval from the Institutional Review Board of the University of Texas Health Science Center at Houston, and written informed consent was obtained from all research participants. Sixteen participants with BD type I were recruited from the UTHealth Mood Disorders outpatient clinic, and 16 healthy controls were recruited from the local community and did not have a personal psychiatric disorder or family history of major psychiatry disorder or neurologic disorders in firstdegree relatives. Specific inclusion criteria for the BD patients were as follows: (a) BD patients with diagnosis of BD I, based on DSM-IV criteria; (b) 18-65 years old; (c) BD patients at any current mood state at the time of the study; (d) BD patients preferably off pharmacological treatment at the time of study, but if not feasible, being on antidepressants and mood stabilizers (including anticonvulsants, typical and atypical antipsychotics and lithium will be allowed). The healthy controls were matched for age, gender, race/ethnic background and socioeconomic status. Subjects with current or past axis I DSM-V psychiatric disorders or first-degree relatives with any axis I psychiatric disorder will be excluded. All subjects completed the Mini-International Neuropsychiatric Interview (MINI) in order to confirm $\mathrm{BD}$ diagnosis in patients or to exclude a history of psychiatric disorders in controls. ${ }^{23} \mathrm{BD}$ participants were also assessed using the MontgomeryÅsberg Depression Rating Scale (MADRS) ${ }^{24}$ and the Young Mania Rating Scale (YMRS) ${ }^{25}$ to index the severity of depressive and manic symptoms, respectively. Functioning was assessed with the Global Assessment of Functioning (GAF) Scale and Functioning Assessment Short Test (FAST) ${ }^{26,27}$

\section{Processing whole-blood samples}

Human blood samples were collected in heparin-coated collection tubes. Then, PBMCs were separated using LeucoPREP brand cell separation tubes (Becton Dickinson Labware, Lincoln Park, NJ, USA). PBMC cell pellets were mixed with RPMI-1640 medium containing 10\% dimethyl sulfate and frozen overnight in a Mr. Frosty container with 2-propanol (\#5100-0001, Nalgene, Rochester, NY, USA) at $-80^{\circ} \mathrm{C}$ following an appropriate postprocessing delay.

\section{Quantification of the intrinsic apoptotic pathway}

The intrinsic apoptotic pathway was assayed using multiplex fluorescent immunoassay kits (Bio-Plex Pro RBM apoptosis assays). The XMAP platform used here was based on the Rules-Based Medicine (RBM) fluorescent beads and antibody pairs. These are sensitive, specific and widely used reagents, sourced by numerous manufacturer's and the data collected using XMAP multiplex beads are widely reported in the literature in studies in which multiple proteins are assayed simultaneously. Total cellular extracts from the PBMC cells were prepared by lysing the cells in lysate dilution buffer according to the manufacturer's instructions, followed by centrifugation at $4{ }^{\circ} \mathrm{C}$ for $10 \mathrm{~min}$ at $10000 \mathrm{~g}$.
The assays were conducted in 96-well polystyrene, round-bottom microplates. Initially, blocker $(10 \mu \mathrm{l})$ was added to all wells of the plate. Next, $30 \mu \mathrm{l}$ of the standard, control or total extracts were added to each well, as indicated. A $10 \mu \mathrm{l}$ aliquot of the working bead mixture was transferred into the wells. The plate was incubated on a plate shaker $(850 \mathrm{r}$. p.m.) in the dark at RT for $60 \mathrm{~min}$. The plate was then placed in the magnetic separator and incubated for separation for $60 \mathrm{~s}$. The supernatant was carefully removed from each well by manual inversion. Beads were washed 3 times by adding $100 \mu \mathrm{l}$ of assay buffer into each well to ensure the absence of any undesirable or non-specifically bound antibodies. After this protocol, $40 \mu \mathrm{l}$ of a detection antibody were added to each well. Incubation was again conducted in darkness and at RT on a plate shaker (850 r.p.m.) for $60 \mathrm{~min}$. Finally, $20 \mu \mathrm{l}$ of streptavidin-PE was added to each well. The plate was incubated on a plate shaker (850 r.p.m.) in the dark at RT for $30 \mathrm{~min}$. The supernatant was carefully removed after magnetic separation of the beads by manual inversion, and washing was performed as previously described. Assay buffer $(100 \mu \mathrm{l})$ was added into each well, and the plate was placed onto a plate shaker for approximately $30 \mathrm{~s}$ in order to achieve gentle agitation of the beads. Samples were run in duplicate using a Bioplex system (Bio-Plex 200 Systems, BioRad, Hercules, (A, USA) and data analysis was conducted in Bio-Plex Manager 4.0 using a 5-parameter logistic regression model.

\section{Gene expression}

PBMCs from each subject were used for total RNA isolation using the RNeasy Plus Mini Kit (Qiagen, Germantown, MD, USA), according to the manufacturer's instructions. After quantification on NanoDrop (Uniscience, Hialeah, $\mathrm{FL}, \mathrm{USA}$ ), the RNA samples were converted to complementary DNA (CDNA) with the High-Capacity cDNA Reverse Transcription Kit (Applied Biosystems, Foster City, CA, USA). The CDNA synthesis was performed in a final volume of $10 \mu \mathrm{l}$ with $2 \mu \mathrm{l} 10 \mathrm{x}$ RT buffer, $0.8 \mu \mathrm{l} 25 \times$ dNMT Mix, $2 \mu \mathrm{l} 10 \times$ RT random primers and $1 \mu \mathrm{l}$ Multiscribe reversetranscriptase (50 units per $\mathrm{ml})$, and the reactions were incubated for $10 \mathrm{~min}$ at $25^{\circ} \mathrm{C}, 2 \mathrm{~h}$ at $37^{\circ} \mathrm{C}$, and $5 \mathrm{~s}$ at $85^{\circ} \mathrm{C}$. Real-time quantitative reverse-transcriptase PCR (qRT-PCR) reactions were performed for the assessment of Mfn1, Mfn2, Opa1, Drp1 and Fis1 gene expression using specific TaqMan FAM/MGB assays (Applied Biosystems, ID assay Hs00966851_m1 for Mfn1, ID assay Hs00208382_m1 for Mfn2, ID assay Hs01047018_m1 for Opa1, ID assay Hs01552605_m1 for Drp1, and Hs00211420_m1 for Fis1). GAPDH (Applied Biosystems, VIC/MGB assay ID Hs99999905_m1) was used as the endogenous control. Reactions were performed in triplicate in a final volume of $12 \mu \mathrm{l}$ containing $6 \mu \mathrm{l} 2 \times$ TaqMan Gene Expression Master Mix, $0.6 \mu \mathrm{l} 20 \times$ TaqMan Gene Expression Assay, $0.6 \mu \mathrm{l} 20 \times$ TaqMan Endogenous Control, $3.8 \mu \mathrm{l}$ of water, and $1 \mu \mathrm{l}$ of CDNA solution, and were run in a QuantStudio 7 Flex Real-Time PCR System (ThermoFischer). Gene expression levels were analyzed by the $\mathrm{ddCt}$ method. $^{28}$

\section{Enzyme-linked immunosorbent assay}

Proteins were extracted from PBMCs using $1 \times$ Cell Lysis Buffer (Bio-Plex Cell Lysis Kit, Bio-Rad, Hercules, CA, USA) containing 500 mm PMSF (SigmaAldrich, St. Louis, MO, USA). Insoluble debris were removed by centrifugation at $4500 \mathrm{~g}$ for $20 \mathrm{~min}$ at $4^{\circ} \mathrm{C}$. Total protein concentration was determined using a BCA assay (Thermo Scientific Pierce). Afterwards, Mfn1, Mfn2, Opa1, Fis1 and Drp1 levels were determined using sandwichELISA assays (MyBioSource, San Diego, CA, USA) according to the manufacturer's instructions. The standard curve demonstrated a direct relationship between optical density (OD) and protein concentration.

\section{Citrate synthase activity}

Citrate synthase activity was assayed according to the method described by Srere, ${ }^{29}$ with a reaction mixture containing $100 \mathrm{mM}$ Tris, $\mathrm{pH} 8.0,0.1 \mathrm{mM}$

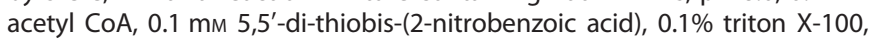
and $2-4 \mu \mathrm{g}$ supernatant protein. The enzymatic reaction was initiated with $0.2 \mu \mathrm{m}$ oxaloacetate and monitored at $412 \mathrm{~nm}$ for $3 \mathrm{~min}$ at $25^{\circ} \mathrm{C}$.

\section{mtDNA copy number}

Real-time quantitative (PCRs) were performed to measure the amount of mitochondrial DNA relative to a single-copy gene (beta-hemoglobin) with a modified protocol from Tyrka and collaborators. ${ }^{30}$ Reactions included $25 \mathrm{ng}$ genomic DNA, $300 \mathrm{nmoll}^{-1}$ of each primer, and $1 \times$ Sybr Select Master Mix (Life Technologies, Carlsbad, CA, USA) in a final volume of $10 \mu \mathrm{l}$. 
Table 1. Demographic characteristics of all subjects

\begin{tabular}{|c|c|c|c|}
\hline & Healthy subjects & Bipolar subjects & P-value \\
\hline$n$ & 16 & 16 & \\
\hline Mean age, years & $33.75 \pm 8.85$ & $35.18 \pm 8.86$ & 0.416 \\
\hline Female gender, $n$ (\%) & $8(50 \%)$ & $8(50 \%)$ & 0.638 \\
\hline Ethnicity (non-Hispanic) & 14 (87.5\%) & $12(75 \%)$ & 0.327 \\
\hline Education (years) & $14.69 \pm 1.662$ & $13.56 \pm 1.861$ & 0.677 \\
\hline Body mass index & $27.43(5.82)$ & $28.22(6.38)$ & 0.717 \\
\hline Smoking & $18.80 \%$ & $37.50 \%$ & 0.217 \\
\hline MADRS & $0.19(0.403)$ & $13.81(10.94)$ & $<0.0001$ \\
\hline YMRS & $0.13(0.342)$ & $7.75(6.97)$ & $<0.0001$ \\
\hline GAF & 90.13 (3.934) & $56.00(11.95)$ & $<0.0001$ \\
\hline FAST & $5.38(6.985)$ & $34.00(16.215$ & $<0.0001$ \\
\hline $\begin{array}{l}\text { Number of manic } \\
\text { episodes }\end{array}$ & NA & 27.38 (49.10) & \\
\hline $\begin{array}{l}\text { Number of hypomanic } \\
\text { episodes }\end{array}$ & NA & $44.75(41.02)$ & \\
\hline $\begin{array}{l}\text { Number of depressive } \\
\text { episodes }\end{array}$ & NA & $29.80(55.56)$ & \\
\hline $\begin{array}{l}\text { Number of mixed } \\
\text { episodes }\end{array}$ & NA & $38.00(50.56)$ & \\
\hline $\begin{array}{l}\text { Number of } \\
\text { hospitalizations }\end{array}$ & NA & $2.63(3.70)$ & \\
\hline Illness duration & NA & $17.43(7.78)$ & \\
\hline $\begin{array}{l}\text { Age at first mania } \\
\text { episode }\end{array}$ & NA & $19.11(6.60)$ & \\
\hline $\begin{array}{l}\text { Age at first depressive } \\
\text { episode }\end{array}$ & NA & $15.31(6.43)$ & \\
\hline \multicolumn{4}{|l|}{ Psychiatric medications (\%) } \\
\hline Lithium & NA & $25.00 \%$ & \\
\hline Antidepressants & NA & $31.30 \%$ & \\
\hline Antipsychotics & NA & $43.80 \%$ & \\
\hline Anticonvulsant & NA & $37.50 \%$ & \\
\hline Benzodiazepines & NA & $18.80 \%$ & \\
\hline Stimulants & NA & $6.30 \%$ & \\
\hline
\end{tabular}

Abbreviations: FAST, Functioning Assessment Short Test; GAF, Global Assessment of Functioning; MADRS, Montgomery-Åsberg Depression Rating Scale; NA, not applicable; YMRS, Young Mania Rating Scale.

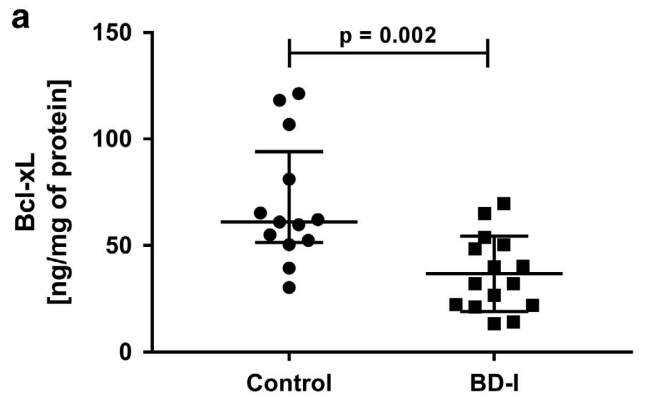

Primer sequences and PCR cycling conditions for both mtDNA and betahemoglobin have been previously reported. ${ }^{30}$ Reactions were carried out in 96-well plates and data were acquired in a QuantStudio 7 Flex Real-Time PCR System (Life Technologies). mtDNA copy number for each sample was determined by relative quantification based on a 5-point standard curve performed with a serial dilution (1:2) of a calibrator sample ranging from 1 to $0.0625 \mathrm{ng}$ DNA. All samples were analyzed in triplicate. The relative amount of mtDNA was finally divided by the relative amount of the betahemoglobin gene to obtain an index of mitochondrial DNA copy number.

Statistical analysis

Statistical analyses were performed using Statistical Package for the Social Sciences, v.23.0 (SPSS, Armonk, NY, USA). Descriptive statistics were used to report demographic and clinical characteristics of the sample. Normality of data distribution was assessed using the Shapiro-Wilk test and histogram visualization. Since the variables being analyzed did not follow a normal distribution, the nonparametric Mann-Whitney U-test was used to test significant differences between the groups. Categorical variables were compared using chi-square or Fisher's exact tests. Correlation analyses were performed using Spearman's rank correlation test. Data are presented as median and interquartile range (IQR). Significance was set at $P<0.05$. Analyses of covariance were used to adjust for possible confounders. We considered all variables associated with diagnostic group and markers with $P<0.20$ to be possible confounding factors. ${ }^{31}$

\section{RESULTS}

Characteristics of BD participants and healthy controls are shown in Table 1. The intrinsic apoptotic pathway and mitochondrial dynamics were evaluated in 16 participants with BD and 16 healthy controls. Notably, no significant differences in sociodemographic factors (ethnicity, socioeconomic status, age, gender, body mass index, education and smoking status) emerged between groups. The mean YMRS score of the BD group was $7.75 \pm 6.97$, and their mean MADRS score was $13.81 \pm 10.94$. Moreover, a significant difference in functional status, assessed by $\operatorname{GAF}(P<0.001)$ and FAST $(P<0.001)$, was found between healthy controls and patients with BD. All patients were on treatment with various psychiatric medications at conventional

b
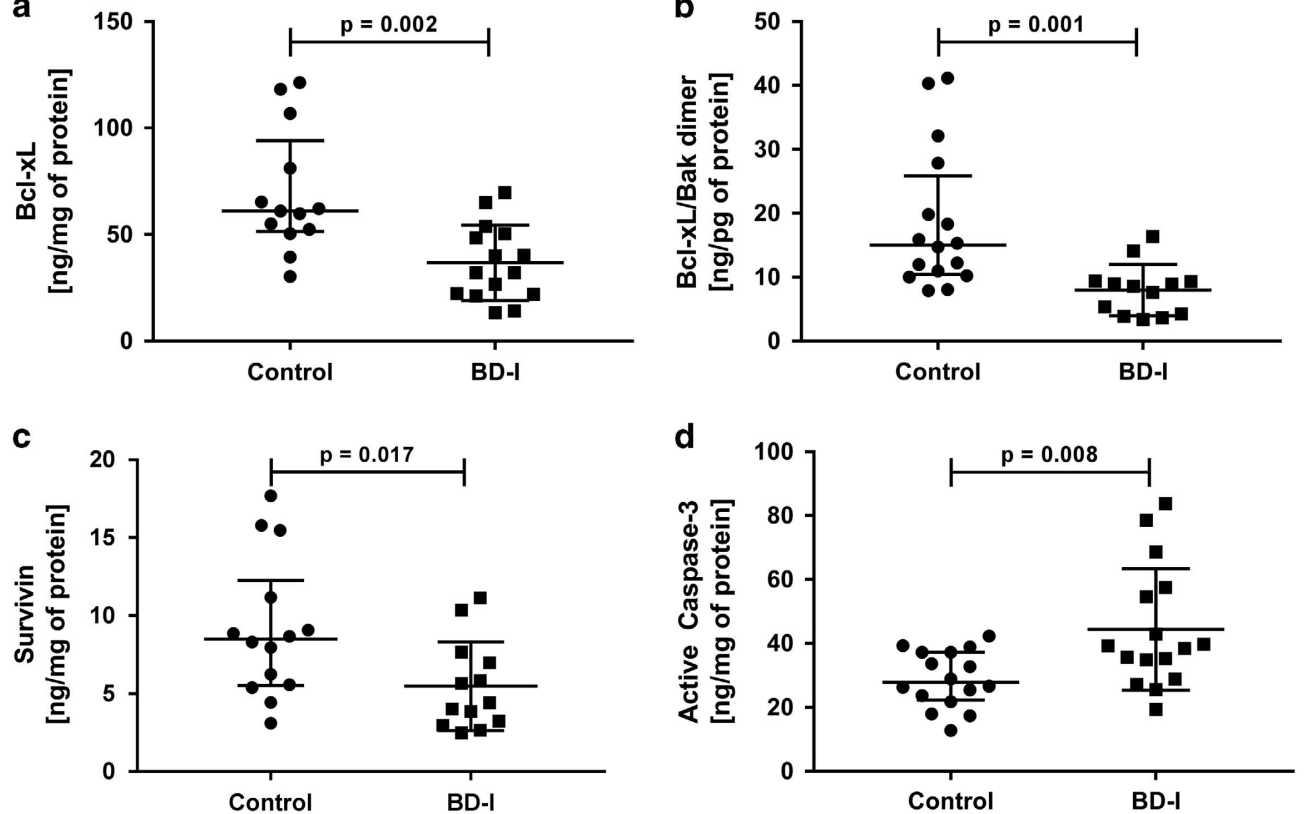

Figure 1. Alteration of anti- and pro-apoptotic proteins in peripheral blood mononuclear cells (PBMCs) from healthy controls and patients with Bipolar Disorder type I (BD-I). (a) Protein levels of Bcl-xL, (b) Protein levels of Bcl-xL/Bak dimer, (c) Protein levels of survivin and (d) Protein levels of active caspase-3. Data were presented as median and interquartile range (IQR). Differences between 2 groups were compared using the Mann-Whitney U-test. Different from the control group; ${ }^{*} P<0.05$. 

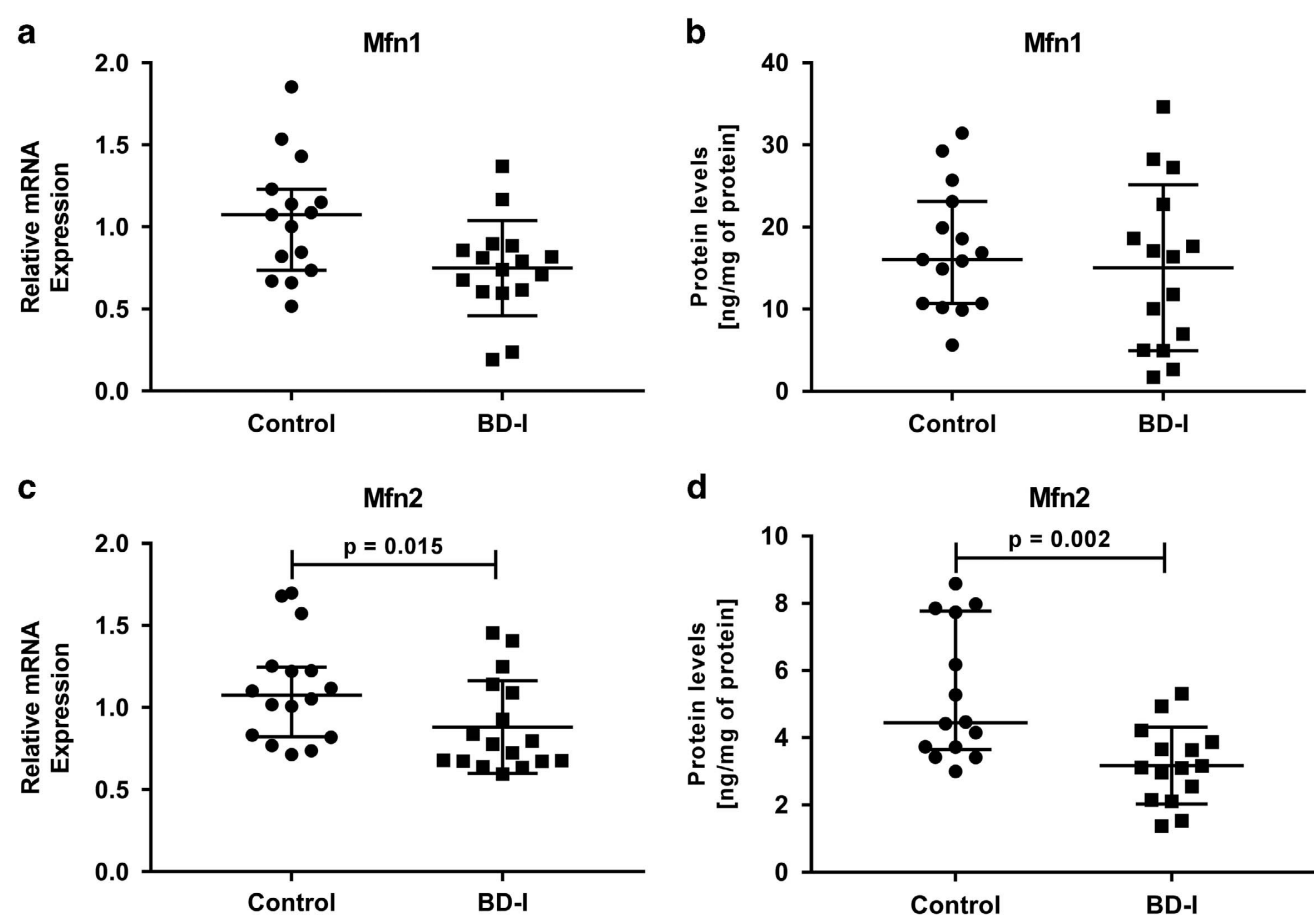

d
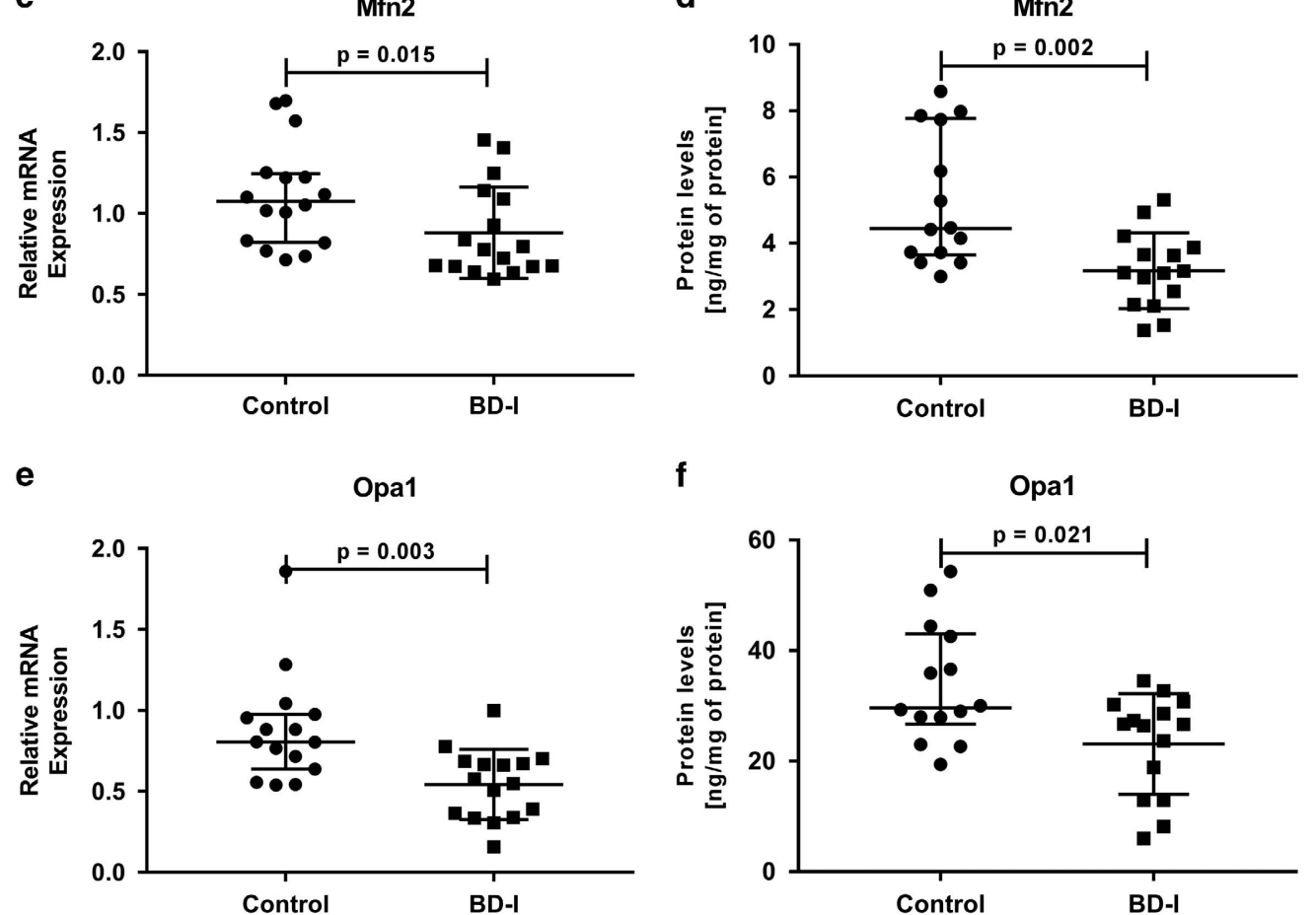

f

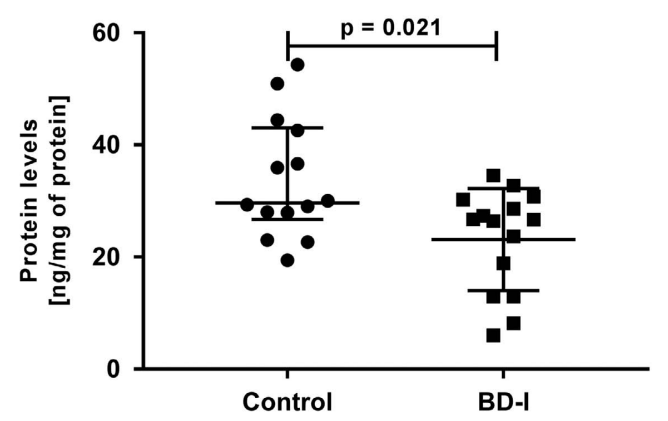

Figure 2. Alteration of mitochondrial fusion proteins in peripheral blood mononuclear cells (PBMCs) from healthy controls and patients with Bipolar Disorder type I (BD-I). (a) Relative mRNA expression of Mfn 1, (b) Protein levels of Mfn 1 (c) Relative mRNA expression of Mfn2, (d) Protein levels of Mfn2, (e) Relative mRNA expression of Opa1, (f) Protein levels of Opa1. Data were presented as median and interquartile range (IQR). Differences between 2 groups were compared using the Mann-Whitney U-test. Different from the control group; ${ }^{*} P<0.05$.

doses at the time of the study, including antipsychotics, anticonvulsants, mood stabilizers and antidepressants. Some patients received additional benzodiazepines and stimulants.

The role of mitochondrial pathway-mediated apoptosis markers in BD was investigated by analyzing the protein levels of bcl-2 family proteins, survivin, smac, and lamin B using multiplex fluorescent immunoassay kits. The levels of the anti-apoptotic proteins $\mathrm{BCl}-\mathrm{xL} \quad(P=0.002), \mathrm{BCl}-\mathrm{xL} / \mathrm{Bak}$ dimer $(P=0.001)$ and survivin $(P=0.017)$ were significantly lower in PBMCs from the $\mathrm{BD}$ group compared to lymphocytes from the healthy control group. However, the levels of active caspase-3 $(P=0.008)$ were significantly higher in lymphocytes from the BD group when compared with healthy controls (Figure 1). In contrast, no differences in the protein levels of the pro-apoptotic factors Bad, Bax, Bad and Smac, or in the anti-apoptotic proteins Mcl-1 and Mcl-1/Bak dimer were found in lymphocytes from the BD group when compared with healthy controls (Supplementary Figure 1S).

To evaluate the mitochondrial dynamics of fusion and fission, we analyzed the mRNA expression and protein levels of Mfn1, Mfn2, Opa1, Drp1 and Fis1. We found that the gene expression of the mitochondrial fusion-related proteins Mfn2 $(P=0.015)$ and Opa1 $(P=0.003)$ was downregulated in the BD group compared to healthy controls (Figures $2 c$ and e, respectively). On the contrary, the gene expression levels of mitochondrial fission-related protein Fis1 $(P=0.003)$ were significantly higher in the BD group compared to healthy controls (Figure 3a). Moreover, there were no significant differences in the gene expression levels of $M f n 1$ and Drp1 in PBMCs between healthy controls or BD subjects (Figures $2 \mathrm{a}$ and $3 \mathrm{c}$, respectively). The overexpression or reduced expression of mitochondrial fission/fusion proteins was confirmed by ELISA analysis. As expected, the results revealed that the protein levels of Mfn2 $(P=0.002)$ and Opa1 $(P=0.021)$ were significantly decreased in $\mathrm{BD}$ patients compared with the controls (Figures 2d and f, respectively), whereas the protein levels of Fis 1 $(P=0.036)$ were significantly increased in lymphocytes from the $\mathrm{BD}$ group when compared with healthy controls (Figure $3 \mathrm{~b}$ ).

In addition, to establish whether the changes observed in the fusion and fission process occurred in conjunction with alterations in mitochondrial mass, we evaluated mitochondrial content by quantifying mtDNA copy number. We observed no significant 
a

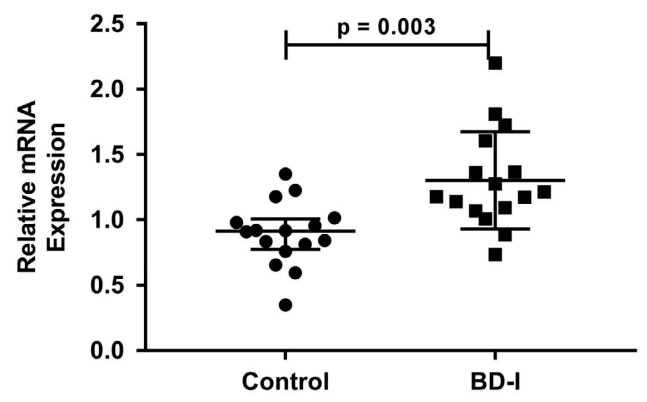

C

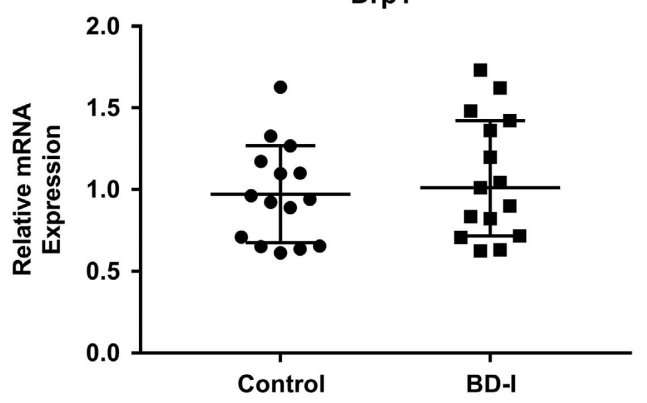

b
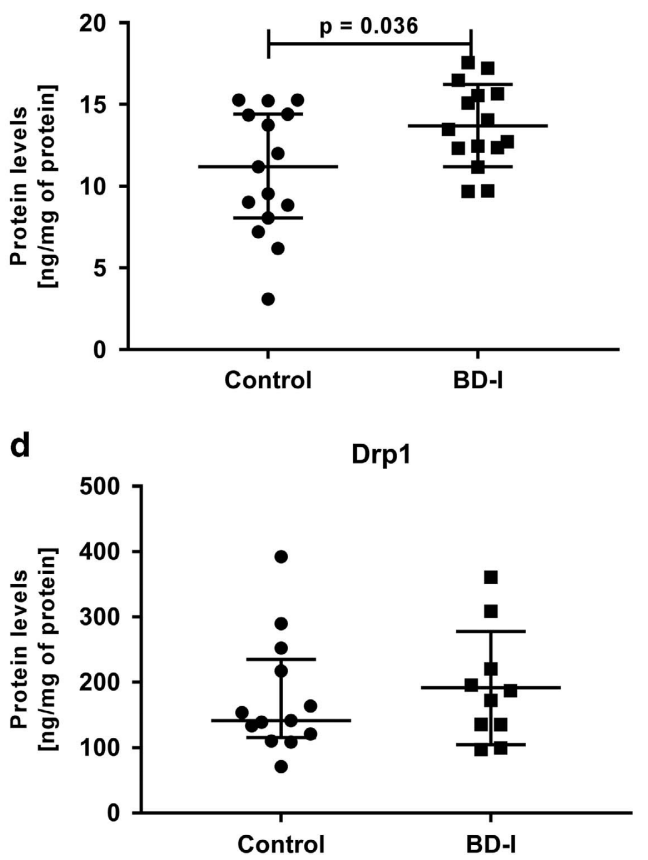

Figure 3. Alteration of mitochondrial fission proteins in peripheral blood mononuclear cells (PBMCs) from healthy controls and patients with Bipolar Disorder type I (BD-I). (a) Relative mRNA expression of Fis1, (b) Protein levels of Fis1, (c) Relative mRNA expression of Drp1, (d) Protein levels of Drp1. Data were presented as median and interquartile range (IQR). Differences between 2 groups were compared using the MannWhitney $U$-test. Different from the control group; ${ }^{*} P<0.05$.

a

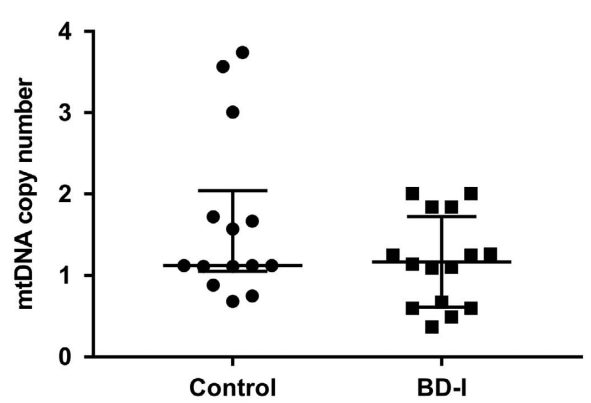

C

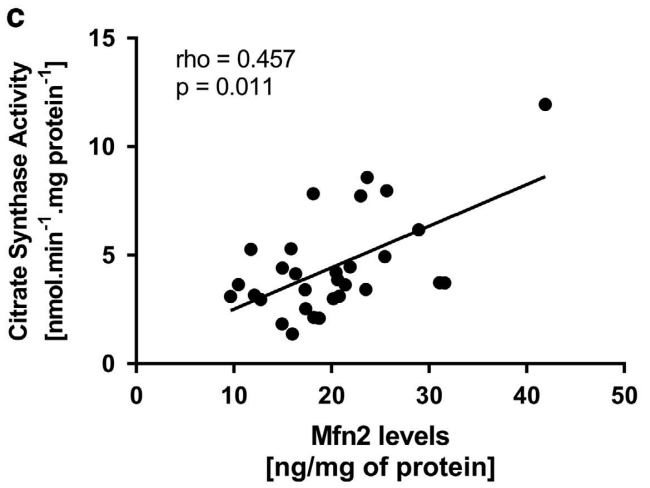

b
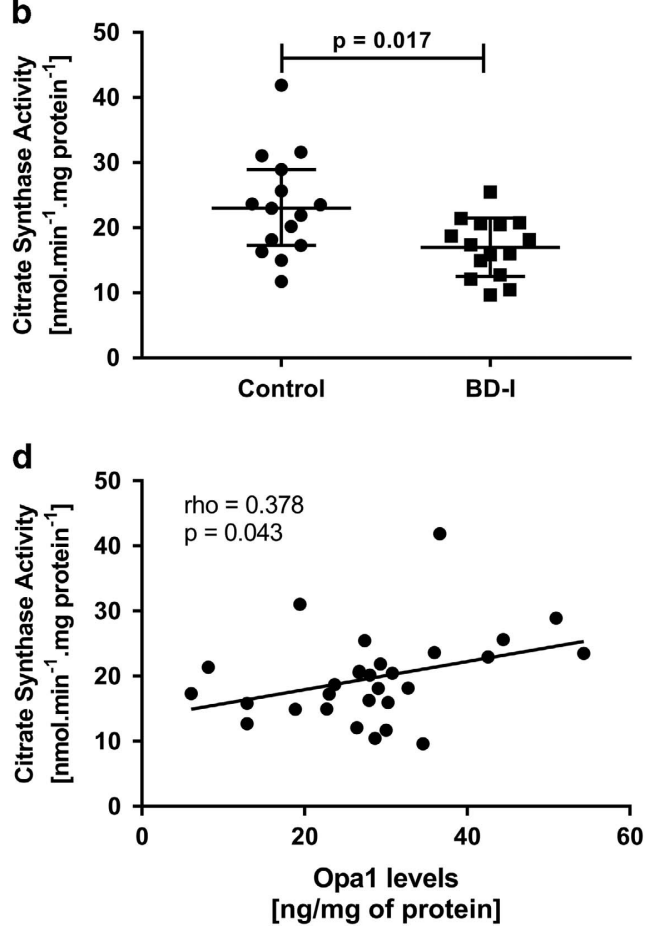

Figure 4. Mitochondrial mass in in peripheral blood mononuclear cells (PBMCs) from healthy controls and patients with Bipolar Disorder type I (BD-I). (a) Distribution of relative mtDNA copy number. (b) Citrate synthase activity. (c) Correlation coefficient (Pearson's correlation coefficient) between citrate synthase activity and protein levels of Mfn2. (d) Correlation coefficient (Spearman's rank correlation test) between citrate synthase activity and protein levels of Opa1. Data were presented as median and interquartile range (IQR). Differences between 2 groups were compared using the Mann-Whitney U-test. Different from the control group; ${ }^{*} P<0.05$. 

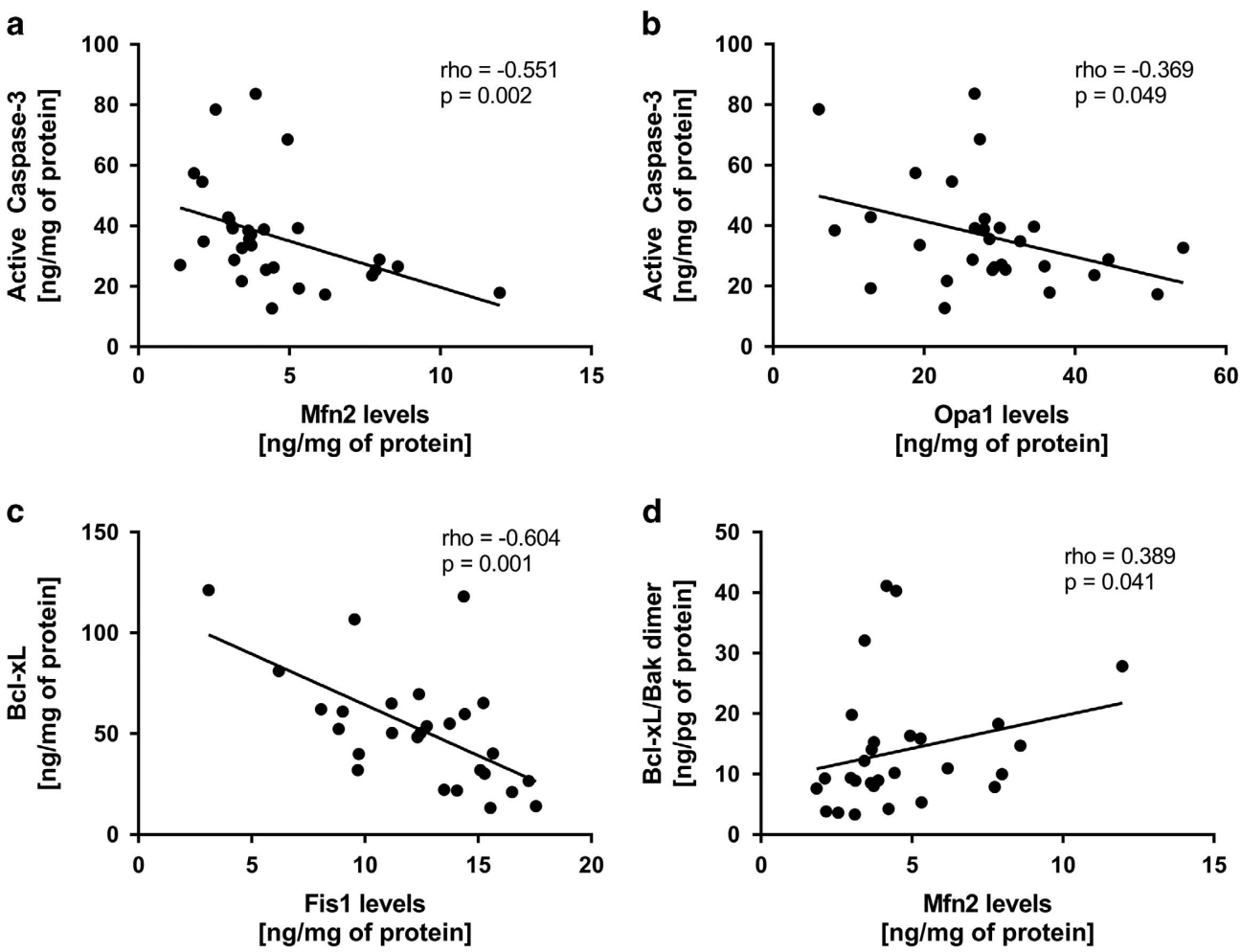

Figure 5. Correlation coefficient of active caspase-3, Bcl-xL and Bcl-xL/Bak dimer protein levels with Mfn2, Opa1 and Fis1 in peripheral blood mononuclear cells (PBMCs) from healthy controls and patients with Bipolar Disorder type I (BD-I). Results were assessed using the Spearman's rank correlation test.

difference in relative mtDNA copy number in the BD group (Figures $4 a, P=0.315)$. To verify whether the $m t D N A$ content in $B D$ was associated with mitochondrial mass, we performed citrate synthase activity assay, an enzymatic marker of mitochondrial mass. We observed a significant decrease in citrate synthase activity in lymphocytes from the BD group when compared with healthy controls (Figures 4b, $P=0.017$ ). Moreover, we also observed positive correlations between mtDNA content and citrate synthase activity (rho $=0.483, P=0.008$ ), suggesting a reduced mitochondrial mass in BD patients. Next, we analyzed the relationship between fusion/fission proteins with citrate activity. As seen in Figure 4c, Mfn2 levels were positively correlated with citrate synthase activity $(r h o=0.457, P=0.011)$. The present results also show a statistically significant correlation between Opa1 protein levels and citrate synthase activity $(r h o=0.378, P=0.043$; Figure $4 d$ ). No correlations were found between Fis 1 protein levels, citrate synthase activity and mtDNA (data not shown).

Since $\mathrm{BCl}-2$ family members play an active role in the regulation of mitochondrial dynamics, we analyzed the relationship between apoptosis and mitochondrial fission/fusion proteins. The present results show that active caspase- 3 was negatively correlated with Mfn2 levels (rho $=-0.551, P=0.002$ ) and Opa1 levels (rho $=$ $-0.369, P=0.049$ ). Also, a significant negative correlation was found between $\mathrm{Bcl}-\mathrm{xL}$ and Fis1 levels (rho $=-0.604, P=0.001$ ), while a positive correlation was found between $\mathrm{Bcl}-\mathrm{xL} / \mathrm{Bak}$ dimer and Mfn2 levels (rho $=0.389, P=0.041$; Figure 5). No correlations were found between Mfn2 protein levels and survivin protein levels (rho $=0.065, P=0.748$ ). However, we found a significant positive correlation between Mfn2 mRNA levels and survivin protein levels (rho $=0.432, P=0.024$ ), as well as a positive correlation between Mfn2 mRNA levels and Mfn2 protein levels (rho $=0.420, P=0.021$ ).

Finally, in an attempt to explore the potential clinical correlates of our findings, we tested possible correlations between psychiatric and demographic characteristics and biochemical data. Our results showed no significant differences in the protein levels of apoptotic factors and mitochondrial fission/fusion proteins in patients under treatment with lithium and antipsychotics (data not shown). Moreover, no associations were found between cellular parameters and age, gender, ethnicity, education, body mass index, smoking, number of depressive episodes or number of hospitalizations ( $P>0.05$ for all analyses). However, we found a negative correlation between Mfn2 levels and YMRS (rho $=-0.554, P=0.001$, Figure 6a) and MADRS (rho $=-0.426$, $P=0.019$, Figure $6 \mathrm{~b}$ ) scores, as well as with the number of manic episodes (rho $=-0.551, P=0.035$, Figure $6 \mathrm{c}$ ). Moreover, we also performed an additional analysis to test the hypothesis that the alterations in anti-apoptotic factors and mitochondrial fission/ fusion proteins correlate with the functional status. The results of Spearman's rank correlation showed a positive correlation between the GAF scores and Mfn2 (rho $=0.598, P<0.001$, Figure $6 \mathrm{~d}$ ), as well as with the anti-apoptotic factors $\mathrm{Bcl}-\mathrm{xL}$ (rho $=0.570, P=0.002$, Figure 6e) and $\mathrm{Bcl}-\mathrm{xL} /$ Bak dimer (rho $=$ $0.579, P=0.001$, Figure $6 f$ ). Similarly, FAST scores were negatively correlated with Mfn2 (rho $=-0.401, P=0.025$, Figure $6 \mathrm{~g}$ ), Bcl-xL (rho $=-0.407, P=0.035$, Figure $6 \mathrm{~h}$ ) and $\mathrm{Bcl}-\mathrm{xL} / \mathrm{Bak}$ dimer (rho $=$ $-0.553, P=0.002$, Figure 6i).

\section{DISCUSSION}

Brain imaging studies over the last two decades have confirmed the presence of volumetric abnormalities in patients with BD compared with healthy control subjects, including reductions in gray matter density in the hippocampus, amygdala, frontal cortex, superior temporal gyrus, cerebellum, and ventricular systems. ${ }^{32-37}$ Previous studies have also reported that the number and size of glia and neurons are reduced in some of these brain areas, ${ }^{38,39}$ suggesting the involvement of apoptosis in the pathophysiology of BD. However, the specific processes of apoptosis in BD have not been fully elucidated. In this study, we have investigated the levels 

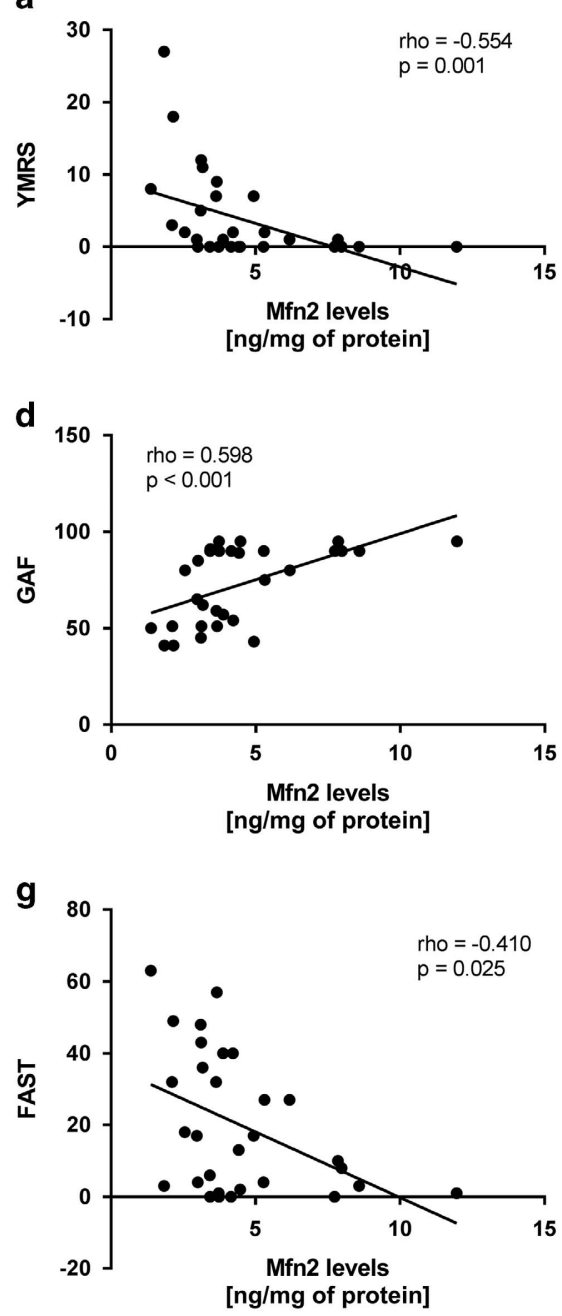

b

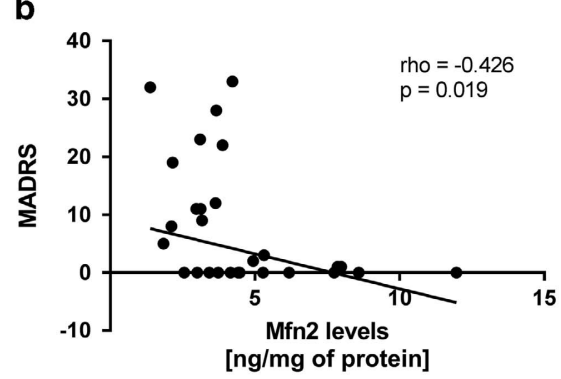

e
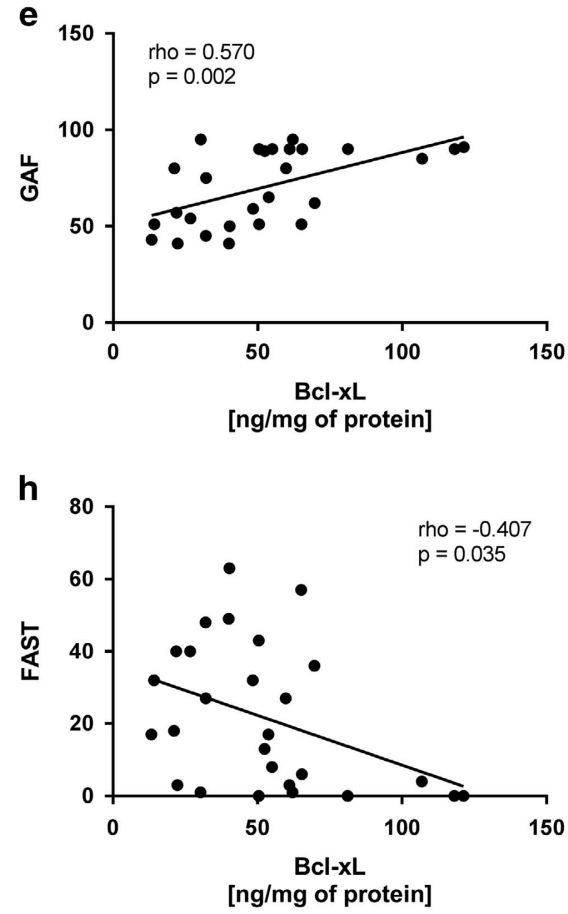
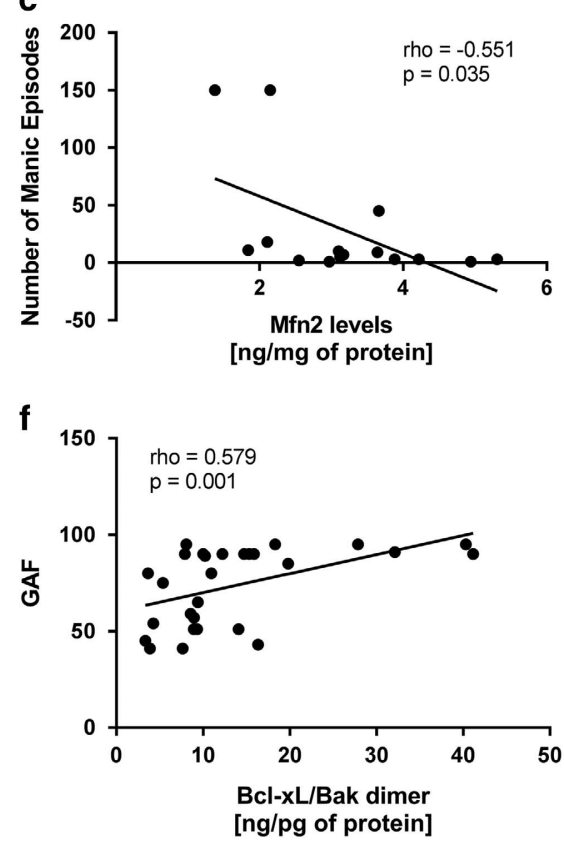

Figure 6. Correlation coefficient of Young Mania Rating Scale (YMRS) score (a), Montgomery-Asberg Depression Scale (MADRS) score (b), number of manic episodes (c), Functional Assessment Screening Tool (FAST) scale (d) and Global Assessment of Functioning (GAF) scale (e) with Mfn2 protein levels in peripheral blood mononuclear cells (PBMCs) from healthy controls and patients with Bipolar Disorder type I (BD-I). Results were assessed using the Spearman's rank correlation test.

of several survival-related and pro-apoptotic proteins in PBMCs of BD participants, and we observed significant alterations compared to healthy controls, including marked decreases in the levels of $\mathrm{Bcl}-\mathrm{xL}$, survivin and $\mathrm{BCl}-\mathrm{xL} / \mathrm{Bak}$ dimers and an increase in the caspase-3 protein levels. Our results are thus in agreement with previous studies showing changes in apoptosis in PBMCs of patients with $\mathrm{BD}$ and in postmortem prefrontal cortex from $\mathrm{BD}$ patients. ${ }^{12,15,40}$

Mitochondria play a key role in the regulation of apoptosis. ${ }^{41}$ Specifically, the release of various pro-apoptotic proteins that are normally present in the intermembrane space of these organelles, such as the cytochrome $c$, is observed during the early stages of apoptotic cell death. ${ }^{14,42}$ Anti-apoptotic members of the $\mathrm{Bcl}-2$ family, such as $\mathrm{BCl}-2$ or $\mathrm{BCl}-\mathrm{xL}$, inhibit Bax or Bak activation, as members of the $\mathrm{Bcl}-\mathrm{xL}$ protein family contain $\mathrm{BH} 1$ and $\mathrm{BH} 2$ domains which are required for heterodimerization with Bak and the inhibition of cell apoptosis. ${ }^{43}$ Consistent with this, we observed a decrease in $\mathrm{BCl}-\mathrm{xL}$ and $\mathrm{BCl}-\mathrm{xL} / \mathrm{Bak}$ heterodimers, suggesting that $\mathrm{Bcl}-\mathrm{xL}$ cannot protect against apoptosis by inhibiting Bak oligomerization. This can lead to the formation of mitochondrial pores and allows the release of intermembrane space proteins that can either act as cofactors for the assembly of the Apaf-1/caspase- 9 apoptosome or promote other downstream events in apoptosis, ultimately leading to caspase- 3 activation and subsequent cell death. Moreover, to our knowledge, this is the first study to show significantly lower levels of survivin in PBMCs of BD patients compared to healthy controls. Survivin, a member of the family of inhibitors of apoptosis proteins (IAPs), is a bifunctional protein that regulates cell division and suppresses apoptosis. ${ }^{44,45}$ It represents a chromosomal passenger protein that binds to caspases, both the effectors caspase- 3 and caspase- 7 and the initiator caspase- $9{ }^{46-48}$ thus protecting cells from apoptosis. Iscru et al. (2013) reported that survivin was also involved in LTP in the hippocampus, suggesting that survivin is involved in hippocampal synaptic plasticity either by compromising hippocampal neurogenesis or by direct interactions with signaling cascades such as NF-kappa B that are involved in hippocampal synaptic plasticity and learning. Thus, a marked decrease of survivin in PBMCs of BD patients would change the balance between the levels of active caspases and IAPs, allowing the active caspases to execute apoptosis. Finally, if taken as a proxy of the brain, the decrease detected in our sample could lead to neuronal loss and impaired synaptic plasticity in BD patients. Corroborating this hypothesis, our results showed higher levels of active caspase-3.

Of note, the interplay between the $\mathrm{BCl}-2$ family and mitochondria is not limited to the intrinsic pathway. $\mathrm{Bcl}-2$ family members 


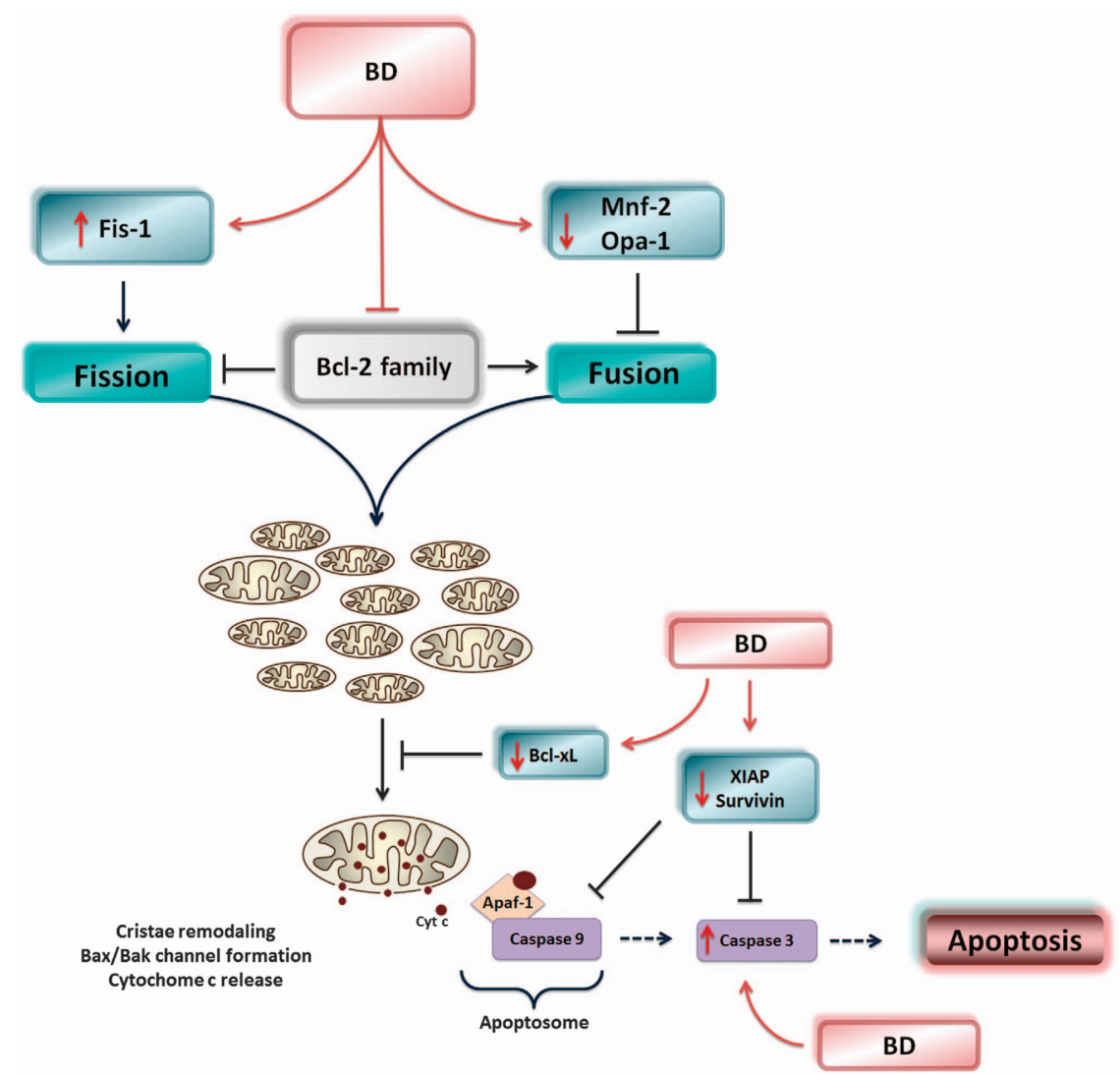

Figure 7. Schematic diagram illustrating the disruption of the balance between mitochondrial fusion and fission in bipolar disorder (BD) patients, and also the modulation of Bcl-2 family. This imbalance in mitochondrial fission and fusion towards fission causes mitochondrial fragmentation and may directly drive the cell into apoptosis, leading to the release of pro-apoptotic proteins, cristae remodeling, and activation of caspase-3. Moreover, members of the Bcl-2 family may participate in the regulation of mitochondrial fission/fusion dynamics in BD patients.

play an active role in the regulation of mitochondrial dynamics, mitochondrial respiration, metabolism, and apoptotic resistance. ${ }^{49-52}$ In this study, real-time PCR and ELISA were used to measure the expression and protein levels of mitochondrial fusion/fission proteins in PBMCs from BD patients. Compared to healthy controls, BD patients showed downregulation of $M f n 2$ and Opa1 and upregulation of Fis 1 both in terms of gene expression and protein levels. Having analyzed mtDNA, we also observed a trend for a decrease in copy number in the BD group. Our results are in accordance with a previous study in leukocyte mtDNA, which showed a slight decrease in baseline mtDNA content in type I BD compared to controls. Of note, our results show that patients present a decrease in the activity of citrate synthase, a marker of mitochondrial content, which were positively correlated with mtDNA. Moreover, decreased Mfn2 protein levels were correlated with the activity of citrate synthase and mtDNA, suggesting that Mfn2 is essential for the regulation of mitochondrial morphology by tipping the balance towards mitochondrial fragmentation. Our results are supported by a study published by Cataldo et $a .^{53}$ demonstrating that prefrontal cortex neurons of postmortem brain from patients with $\mathrm{BD}$ and peripheral cells from $\mathrm{BD}$ patients display morphological abnormalities (more mitochondria of smaller size) and an abnormal pattern of clumping and marginalization in the intracellular distribution of mitochondria. Taken together, these results suggest that these mitochondrial structural abnormalities may represent an attempt to overcome a reduced mitochondrial network connectivity, as determined by the balance between fusion and fission processes.

Several studies have demonstrated that alterations in proteins involved in mitochondrial fusion and fission lead to altered mitochondrial shape, loss of mtDNA, decrease in mitochondrial respiration, increased oxidative stress and apoptotic cell death. ${ }^{54-57}$ Mfn2 expression controls the expression of oxidative phosphorylation, and the inhibition of Mfn2 expression is associated with a reduced mitochondrial membrane potential, impaired glucose oxidation and a downregulation of oxidative phosphorylation subunits, all of which markedly alters the extent of the mitochondrial network. ${ }^{58,59}$ Mfn2 deficiency also increases the mitochondrial Bax/Bcl-2 ratio, indicating that Mfn2 deficiency potentially induces apoptosis through the $\mathrm{Bcl}-2$ and $\mathrm{Bax}$ pathway. ${ }^{60}$ Depletion of Opa1 or mitofusins results in poor cell growth and enhances susceptibility to apoptotic stimuli ${ }^{55,61,62}$ because loss of the inner mitochondrial membrane protein Opa1 leads to drastic reorganization of mitochondrial cristae, fragmentation of mitochondria, efflux of cytochrome $c$, and apoptosis. ${ }^{61}$ Moreover, excessive mitochondrial fission mediated by Drp1 and Fis1 produces dysfunctional mitochondrial fragments that show increased production of reactive oxygen species and are also more sensitive to mitochondrial permeability transition pore opening and Bax/Bak activation. ${ }^{49,63}$ In this study, we showed that patients with BD demonstrated increased levels of active caspase-3, which were shown to be negatively correlated with Mfn2 and Opa1. Thus, the downregulation of Mfn2 and Opa1 and overexpression of Fis1 observed in BD patients can induce mitochondrial fission and apoptosis because mitochondrial fragmentation induced by Fis 1 is followed by cytochrome $c$ release, caspase activation and cell death. ${ }^{64}$ Taken together, we suggest that an imbalance in mitochondrial fission and fusion towards fission causes mitochondrial fragmentation and may drive the cell into apoptosis, leading to the release of pro-apoptotic proteins, cristae remodeling, and 
activation of caspase-3. Moreover, Bcl-2 family members may participate in the regulation of mitochondrial fission/fusion dynamics in $\mathrm{BD}$ patients because $\mathrm{Bcl}-2$ levels were markedly decreased in BD patients, ${ }^{12,15}$ and this protein has an antagonistic effect on mitochondrial fission machinery mediated by the mutually exclusive interactions of $\mathrm{Bcl}-2$ and Drp1 with $\mathrm{Fis}^{165}$ In support of this hypothesis, we found that the levels of $B c l-x L$ and $\mathrm{BCl}-\mathrm{xL} / \mathrm{Bak}$ dimer, members of the $\mathrm{Bcl}-2$ family, were correlated with Mfn2 and Fis 1 levels, suggesting that $\mathrm{Bcl}-2$ family can regulate mitochondrial fission/fusion dynamics in BD patients (Figure 7).

Several studies have shown parallel alterations in central nervous system and peripheral cells of patients with BD. In addition, BD patients show higher rates of medical comorbidities, including cardiovascular disease, diabetes mellitus and obesity, which led some investigators to conceptualize BD as a multisystemic disease. ${ }^{66-68}$ In other words, peripherally-measured parameters can not only provide biomarkers of illness, but are also thought to influence behavior, cognitive and functional parameters. To corroborate this hypothesis, our results showed that individuals with worse functional status (as shown by lower GAF and higher FAST scores) showed significantly lower levels of fusions proteins Mfn2 and Opa1 and higher levels of Fis1. In the same line, we also found a negative correlation between functional status and $\mathrm{BCl}-\mathrm{xL}$ and $\mathrm{Bcl}-\mathrm{xL} / \mathrm{Bak}$ dimer. Accordingly, the changes in fission/fusion protein levels and anti-apoptotic factors observed in PBMCs from BD patients can support the relevance of the peripheral findings to mitochondrial abnormalities reported in the central nervous system of BD patients.

Our results should be interpreted in light of their limitations. First, our sample size was relatively small and this may limit the interpretation of our results. Second, it cannot be excluded that long-term treatment with psychiatric medications may affect the mitochondrial network. Third, our study was limited to mitochondrial analyzes that could be performed on frozen PBMC samples, which precluded us from assessing of other relevant mitochondrial parameters, such as oxygen consumption. Thus, future studies are necessary to verify these findings in larger and fresh samples, allowing the specific preparation of tissues for the analysis of mitochondrial morphology. These studies will be able to evaluate the morphological consequences of the imbalance of mitochondrial dynamics in patients with $\mathrm{BD}$.

In conclusion, our results demonstrate significant changes in the expression of mitochondrial fission and fusion proteins and survival-related proteins in PBMCs from BD. Our findings in PBMCs of patients with $\mathrm{BD}$ support a link between mitochondrial dysfunction and the pathophysiology of $B D$, and the fact that these changes are seen in peripheral PBMCs suggests that the pathophysiological processes active in the disorder are body-wide and implicate circulating factors. ${ }^{69}$ Finally, understanding the mitochondrial network dynamics in BD and its interconnection with cellular signaling pathways may contribute to a more comprehensive understanding of the biological processes in this disease and may ultimately lead to the development of new treatment strategies. $^{70}$

\section{CONFLICT OF INTEREST}

The authors declare no conflict of interest.

\section{ACKNOWLEDGMENTS}

This study was supported in part by grants from the Pat Rutherford, Jr Endowed Chair in Psychiatry (JCS), John S. Dunn Foundation from United States (JCS) and NIMH (R01MH085667-01A1; JCS). MB is supported by a NHMRC Senior Principal Research Fellowship 1059660. The Center of Excellence on Mood Disorders and Translational Psychiatry Program (USA) is funded by the Department of Psychiatry and Behavioral Sciences, McGovern Medical School, The University of Texas Medical School at Houston. The Laboratory of Neurosciences (Brazil) is one of the centers of the
National Institute for Molecular Medicine (INCT-MM) and one of the members of the Center of Excellence in Applied Neurosciences of Santa Catarina (NENASC). Giselli Scaini thanks the Conselho Nacional de Desenvolvimento Científico e Tecnológico (CNPq) for a postdoctoral fellowship (205680/2014-3).

\section{REFERENCES}

1 Merikangas KR, Jin R, He JP, Kessler RC, Lee S, Sampson NA et al. Prevalence and correlates of bipolar spectrum disorder in the world mental health survey initiative. Arch Gen Psychiatry 2011; 68: 241-251.

2 Osby U, Brandt L, Correia N, Ekbom A, Sparen P. Excess mortality in bipolar and unipolar disorder in Sweden. Arch Gen Psychiatry 2001; 58: 844-850.

3 Martinez-Aran A, Vieta E, Torrent C, Sanchez-Moreno J, Goikolea JM, Salamero M et al. Functional outcome in bipolar disorder: the role of clinical and cognitive factors. Bipol Disord 2007; 9: 103-113.

4 Berk M, Kapczinski F, Andreazza AC, Dean OM, Giorlando F, Maes M et al. Pathways underlying neuroprogression in bipolar disorder: focus on inflammation, oxidative stress and neurotrophic factors. Neurosci Biobehav Rev 2011; 35: 804-817.

5 Torres IJ, Boudreau VG, Yatham LN. Neuropsychological functioning in euthymic bipolar disorder: a meta-analysis. Acta Psychiatr Scand Suppl 2007; 434: 17-26.

6 Rosa AR, Gonzalez-Ortega I, Gonzalez-Pinto A, Echeburua E, Comes M, MartinezAran A et al. One-year psychosocial functioning in patients in the early vs. late stage of bipolar disorder. Acta Psychiatr Scand 2012; 125: 335-341.

7 Elshahawi HH, Essawi H, Rabie MA, Mansour M, Beshry ZA, Mansour AN. Cognitive functions among euthymic bipolar I patients after a single manic episode versus recurrent episodes. J Affect Disord 2011; 130: 180-191.

8 Cannon $\mathrm{M}$, Jones $\mathrm{P}$, Gilvarry $\mathrm{C}$, Rifkin L, McKenzie K, Foerster A et al. Premorbid social functioning in schizophrenia and bipolar disorder: similarities and differences. Am J Psychiatry 1997; 154: 1544-1550.

9 Rosa AR, Magalhaes PV, Czepielewski L, Sulzbach MV, Goi PD, Vieta E et al. Clinical staging in bipolar disorder: focus on cognition and functioning. J Clin Psychiatry 2014; 75: e450-e456.

10 Scola G, Kim HK, Young LT, Andreazza AC. A fresh look at complex I in microarray data: clues to understanding disease-specific mitochondrial alterations in bipolar disorder. Biol Psychiatry 2013; 73: e4-e5.

11 Gould TD, Manji HK. Signaling networks in the pathophysiology and treatment of mood disorders. J Psychosom Res 2002; 53: 687-697.

12 Kim HW, Rapoport SI, Rao JS. Altered expression of apoptotic factors and synaptic markers in postmortem brain from bipolar disorder patients. Neurobiol Dis 2010; 37: 596-603.

13 Gigante AD, Young LT, Yatham LN, Andreazza AC, Nery FG, Grinberg LT et al. Morphometric post-mortem studies in bipolar disorder: possible association with oxidative stress and apoptosis. Int J Neuropsychopharmacol 2011; 14: 1075-1089.

14 Green DR, Reed JC. Mitochondria and apoptosis. Science 1998; 281: 1309-1312.

15 Moutsatsou P, Tsoporis JN, Salpeas V, Bei E, Alevizos B, Anagnostara C et al. Peripheral blood lymphocytes from patients with bipolar disorder demonstrate apoptosis and differential regulation of advanced glycation end products and S100B. Clin Chem Lab Medicine 2014; 52: 999-1007.

16 Bei E, Salpeas V, Pappa D, Anagnostara C, Alevizos V, Moutsatsou P. Phosphorylation status of glucocorticoid receptor, heat shock protein 70 , cytochrome $\mathrm{c}$ and Bax in lymphocytes of euthymic, depressed and manic bipolar patients. Psychoneuroendocrinology 2009; 34: 1162-1175.

17 Fries GR, Vasconcelos-Moreno MP, Gubert C, Santos BT, da Rosa AL, Eisele B et al. Early apoptosis in peripheral blood mononuclear cells from patients with bipolar disorder. J Affect Disord 2014; 152-154: 474-477.

18 Niizuma K, Yoshioka H, Chen H, Kim GS, Jung JE, Katsu M et al. Mitochondrial and apoptotic neuronal death signaling pathways in cerebral ischemia. Biochim Biophys Acta 2010; 1802: 92-99.

19 Pieczenik SR, Neustadt J. Mitochondrial dysfunction and molecular pathways of disease. Exp Mol Pathol 2007; 83: 84-92.

20 Kroemer G, Reed JC. Mitochondrial control of cell death. Nat Med 2000; 6: 513-519.

21 Arnoult D, Grodet A, Lee YJ, Estaquier J, Blackstone C. Release of OPA1 during apoptosis participates in the rapid and complete release of cytochrome $c$ and subsequent mitochondrial fragmentation. J Biol Chem 2005; 280: 35742-35750.

22 Arnoult D, Rismanchi N, Grodet A, Roberts RG, Seeburg DP, Estaquier J et al. Bax/ Bak-dependent release of DDP/TIMM8a promotes Drp1-mediated mitochondrial fission and mitoptosis during programmed cell death. Curr Biol 2005; 15: 2112-2118.

23 Sheehan DV, Lecrubier Y, Sheehan KH, Amorim P, Janavs J, Weiller E et al. The Mini-International Neuropsychiatric Interview (M.I.N.I.): the development and validation of a structured diagnostic psychiatric interview for DSM-IV and ICD-10. J Clin Psychiatry 1998; 59(Suppl 20): 22-33, quiz 34-57. 
24 Williams JB, Kobak KA. Development and reliability of a structured interview guide for the Montgomery Asberg Depression Rating Scale (SIGMA). Br J Psychiatry 2008; 192: $52-58$.

25 Young RC, Biggs JT, Ziegler VE, Meyer DA. A rating scale for mania: reliability, validity and sensitivity. Br J Psychiatry 1978; 133: 429-435.

26 American Psychiatric Association. Diagnostic and Statistical Manual of Mental Disorders, Text Revision (DSM-IV-TR). 4th edn.

27 Rosa AR, Sanchez-Moreno J, Martinez-Aran A, Salamero M, Torrent C, Reinares M et al. Validity and reliability of the Functioning Assessment Short Test (FAST) in bipolar disorder. Clin Pract Epidemiol Mental Health 2007; 3: 5.

28 Livak KJ, Schmittgen TD. Analysis of relative gene expression data using real-time quantitative PCR and the 2(-Delta Delta C(T)) Method. Methods 2001; 25: 402-408.

29 Srere PA. Citrate synthase. Methods Enzymol 1969; 13: 3-11.

30 Tyrka AR, Parade SH, Price LH, Kao HT, Porton B, Philip NS et al. Alterations of mitochondrial DNA copy number and telomere length with early adversity and psychopathology. Biol Psychiatry 2016; 79: 78-86.

31 Victora CG, Huttly SR, Fuchs SC, Olinto MT. The role of conceptual frameworks in epidemiological analysis: a hierarchical approach. Int J Epidemiol 1997; 26: 224-227.

32 Bauer IE, Ouyang A, Mwangi B, Sanches M, Zunta-Soares GB, Keefe RS et al. Reduced white matter integrity and verbal fluency impairment in young adults with bipolar disorder: a diffusion tensor imaging study. J Psychiatr Res 2015; 62: 115-122.

33 Brambilla P, Stanley JA, Nicoletti MA, Sassi RB, Mallinger AG, Frank E et al. $1 \mathrm{H}$ magnetic resonance spectroscopy investigation of the dorsolateral prefrontal cortex in bipolar disorder patients. J Affect Disord 2005; 86: 61-67.

34 Hibar DP, Westlye LT, van Erp TG, Rasmussen J, Leonardo CD, Faskowitz J et al. Subcortical volumetric abnormalities in bipolar disorder. Mol Psychiatry 2016; 21: 1710-1716.

35 Bertolino A, Frye M, Callicott JH, Mattay VS, Rakow R, Shelton-Repella J et al. Neuronal pathology in the hippocampal area of patients with bipolar disorder: a study with proton magnetic resonance spectroscopic imaging. Biol Psychiatry 2003; 53: 906-913.

36 Dager SR, Friedman SD, Parow A, Demopulos C, Stoll AL, Lyoo IK et al. Brain metabolic alterations in medication-free patients with bipolar disorder. Arch Gen Psychiatry 2004; 61: 450-458.

37 De Peri L, Crescini A, Deste G, Fusar-Poli P, Sacchetti E, Vita A. Brain structural abnormalities at the onset of schizophrenia and bipolar disorder: a meta-analysis of controlled magnetic resonance imaging studies. Curr Pharm Design 2012; 18: 486-494.

38 Brauch RA, Adnan El-Masri M, Parker JC Jr, El-Mallakh RS. Glial cell number and neuron/glial cell ratios in postmortem brains of bipolar individuals. J Affect Disord 2006; 91: 87-90.

39 Rajkowska G, Halaris A, Selemon LD. Reductions in neuronal and glial density characterize the dorsolateral prefrontal cortex in bipolar disorder. Biol Psychiatry 2001; 49: 741-752.

40 Benes FM, Matzilevich D, Burke RE, Walsh J. The expression of proapoptosis genes is increased in bipolar disorder, but not in schizophrenia. Mol Psychiatry 2006; 11: 241-251.

41 Gogvadze V, Orrenius S. Mitochondrial regulation of apoptotic cell death. Chemicobiol Interactions 2006; 163: 4-14.

42 Cai J, Yang J, Jones DP. Mitochondrial control of apoptosis: the role of cytochrome c. Biochim Biophys Acta 1998; 1366: 139-149.

43 Shamas-Din A, Kale J, Leber B, Andrews DW. Mechanisms of action of Bcl-2 family proteins. Cold Spring Harb Perspect Biology 2013; 5: a008714.

44 Salvesen GS, Duckett CS. IAP proteins: blocking the road to death's door. Nat Rev Mol Cell Biol 2002; 3: 401-410.

45 Altieri DC. Survivin and apoptosis control. Adv Cancer Res 2003; 88: 31-52.

46 Skoufias DA, Mollinari C, Lacroix FB, Margolis RL. Human survivin is a kinetochoreassociated passenger protein. J Cell Biol 2000; 151: 1575-1582.

47 Shin S, Sung BJ, Cho YS, Kim HJ, Ha NC, Hwang Jl et al. An anti-apoptotic protein human survivin is a direct inhibitor of caspase-3 and -7. Biochemistry 2001; 40: 1117-1123.

48 O'Connor L, Harris AW, Strasser A. CD95 (Fas/APO-1) and p53 signal apoptosis independently in diverse cell types. Cancer Res 2000; 60: 1217-1220.

49 Autret A, Martin SJ. Bcl-2 family proteins and mitochondrial fission/fusion dynamics. Cell Mol Life Sci 2010; 67: 1599-1606.
50 Brooks C, Dong Z. Regulation of mitochondrial morphological dynamics during apoptosis by Bcl-2 family proteins: a key in Bak? Cell Cycle 2007; 6: 3043-3047.

51 Martinou JC, Youle RJ. Mitochondria in apoptosis: BCl-2 family members and mitochondrial dynamics. Dev Cell 2011; 21: 92-101.

52 Gottlieb E, Vander Heiden MG, Thompson CB. Bcl-x $(\mathrm{L})$ prevents the initial decrease in mitochondrial membrane potential and subsequent reactive oxygen species production during tumor necrosis factor alpha-induced apoptosis. Mol Cell Biol 2000; 20: 5680-5689.

53 Cataldo AM, McPhie DL, Lange NT, Punzell S, Elmiligy S, Ye NZ et al. Abnormalities in mitochondrial structure in cells from patients with bipolar disorder. Am J Pathology 2010; 177: 575-585.

54 Chen $\mathrm{H}$, Chan DC. Mitochondrial dynamics--fusion, fission, movement, and mitophagy--in neurodegenerative diseases. Hum Mol Genet 2009; 18: R169-R176.

55 Chen $\mathrm{H}$, Chomyn A, Chan DC. Disruption of fusion results in mitochondrial heterogeneity and dysfunction. J Biol Chem 2005; 280: 26185-26192.

56 Chen H, Detmer SA, Ewald AJ, Griffin EE, Fraser SE, Chan DC. Mitofusins Mfn 1 and Mfn2 coordinately regulate mitochondrial fusion and are essential for embryonic development. J Cell Biol 2003; 160: 189-200.

57 Detmer SA, Chan DC. Functions and dysfunctions of mitochondrial dynamics. Nat Rev Mol Cell Biol 2007; 8: 870-879.

58 Bach D, Pich S, Soriano FX, Vega N, Baumgartner B, Oriola J et al. Mitofusin-2 determines mitochondrial network architecture and mitochondrial metabolism. A novel regulatory mechanism altered in obesity. J Biol Chem 2003; 278: 17190-17197.

59 Kelley DE, Goodpaster BH, Storlien L. Muscle triglyceride and insulin resistance. Annu Rev Nutr 2002; 22: 325-346.

60 Zhao N, Zhang Y, Liu Q, Xiang W. Mfn2 affects embryo development via mitochondrial dysfunction and apoptosis. PLOS ONE 2015; 10: e0125680.

61 Olichon A, Baricault L, Gas N, Guillou E, Valette A, Belenguer P et al. Loss of OPA1 perturbates the mitochondrial inner membrane structure and integrity, leading to cytochrome c release and apoptosis. J Biol Chem 2003; 278: 7743-7746.

62 Lee YJ, Jeong SY, Karbowski M, Smith CL, Youle RJ. Roles of the mammalian mitochondrial fission and fusion mediators Fis1, Drp1, and Opa1 in apoptosis. Mol Biol Cell 2004; 15: 5001-5011.

63 Westermann B. Mitochondrial fusion and fission in cell life and death. Nat Rev Mol Cell Biol 2010; 11: 872-884.

64 James DI, Parone PA, Mattenberger Y, Martinou JC. hFis1, a novel component of the mammalian mitochondrial fission machinery. J Biol Chem 2003; 278: 36373-36379.

65 Kong D, Xu L, Yu Y, Zhu W, Andrews DW, Yoon Y et al. Regulation of Ca2+-induced permeability transition by $\mathrm{BCl}-2$ is antagonized by Drpl and hFis1. Mol Cell Biochem 2005; 272: 187-199.

66 Kupfer DJ. The increasing medical burden in bipolar disorder. JAMA 2005; 293: 2528-2530.

67 Leboyer M, Soreca I, Scott J, Frye M, Henry C, Tamouza R et al. Can bipolar disorder be viewed as a multi-system inflammatory disease? J Affect Disord 2012; 141: 1-10.

68 Schloesser RJ, Huang J, Klein PS, Manji HK. Cellular plasticity cascades in the pathophysiology and treatment of bipolar disorder. Neuropsychopharmacology 2008; 33: 110-133.

69 Morris $G$, Berk $M$. The many roads to mitochondrial dysfunction in neuroimmune and neuropsychiatric disorders. BMC Med 2015; 13: 68

70 Dean OM, Turner A, Malhi GS, Ng C, Cotton SM, Dodd S et al. Design and rationale of a 16-week adjunctive randomized placebo-controlled trial of mitochondrial agents for the treatment of bipolar depression. Rev Brasil Psiquiatria 2015; 37: 3-12.

This work is licensed under a Creative Commons Attribution 4.0 International License. The images or other third party material in this article are included in the article's Creative Commons license, unless indicated otherwise in the credit line; if the material is not included under the Creative Commons license, users will need to obtain permission from the license holder to reproduce the material. To view a copy of this license, visit http://creativecommons.org/licenses/ by/4.0/

(c) The Author(s) 2017

Supplementary Information accompanies the paper on the Translational Psychiatry website (http://www.nature.com/tp) 


\section{University Library}

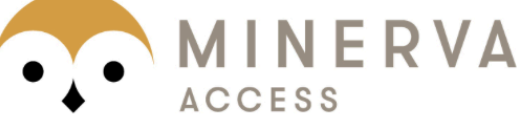

A gateway to Melbourne's research publications

Minerva Access is the Institutional Repository of The University of Melbourne

Author/s:

Scaini, G;Fries, GR;Valvassori, SS;Zeni, CP;Zunta-Soares, G;Berk, M;Soares, JC;Quevedo, J

Title:

Perturbations in the apoptotic pathway and mitochondrial network dynamics in peripheral blood mononuclear cells from bipolar disorder patients

Date:

2017-05-02

\section{Citation:}

Scaini, G., Fries, G. R., Valvassori, S. S., Zeni, C. P., Zunta-Soares, G., Berk, M., Soares, J. C. \& Quevedo, J. (2017). Perturbations in the apoptotic pathway and mitochondrial network dynamics in peripheral blood mononuclear cells from bipolar disorder patients. TRANSLATIONAL PSYCHIATRY, 7 (5), https://doi.org/10.1038/tp.2017.83.

Persistent Link:

http://hdl.handle.net/11343/259225

License:

CC BY 